\title{
Yellow nail syndrome, Phrygian cap gallbladder and Saint's triad? Case report
}

\author{
Vitorino Modesto Santos* \\ Victor Manabu Yano** \\ Gabriel Luan Queiroz Alves da Cunha ${ }^{* * *}$ \\ Mayza Lemes Duarte** \\ Viviane Vieira Passini Soares* \\ Leonardo Frota Boggio ${ }^{* * * *}$
}

\footnotetext{
"Medical Doctor. PhD. Adjunct-professor of Internal Medicine. Armed Forces Hospital and Catholic University Medical Course. Brasília-DF. Brazil.

"Medical resident of first year. Armed Forces Hospital. Brasília. Brazil.

*** Medical resident of second year. Armed Forces Hospital. Brasília. Brazil.

${ }^{* * * * *}$ Medical Doctor. Radiology Service. Armed Forces Hospital. Brasília. Brazil.
}

Correspondence: Dr. Vitorino Modesto Santos. Armed Forces Hospital. Estrada do Contorno do Bosque s/n. Cruzeiro Novo. Zip Code: $70658-900$. Brasília. Brazil. Telephone number: 55-6139662103.E-mail: vitorinomodesto@gmail.com

\section{ABSTRACT}

The yellow nail syndrome is scarcely described and is characterized by dystrophic nails, pulmonary disturbances and lymphedema of extremities. A case of this syndrome is reported in an 89-year-old Brazilian woman with well-controlled diabetes mellitus and arterial hypertension. Additionally to the typical syndrome, the patient also presented pincer nails and yellow-brownish chromonychia. She was admitted because of acute abdominal symptoms associated with sigmoid diverticulitis and an adjacent abscess. The imaging studies revealed pulmonary and pleural changes, in addition to pericardial effusion. Incidentally, the features of Phrygian cap gallbladder anomaly were found. Neither diverticular disease nor gallbladder disorders have been related to yellow nail syndrome. In the present case study, the synchronism between some of these conditions could be casual; but diverticular disease, cholelithiasis, and diaphragmatic hernia are associated in the Saint's triad. MÉD UIS. 2015;28(3):387-91.

Keywords: Diverticulum, Colon. Gallbladder diseases. Hernia, Hiatal.

\section{¿Sindrome de uñas amarillas, vesícula biliar en gorro frigio y triada de Saint? Reporte de caso}

\section{RESUMEN}

El síndrome de las uñas amarillas está poco descrito y se caracteriza por uñas distróficas, trastornos pulmonares y linfedema de las extremidades. Se presenta un caso de este síndrome en una mujer brasileña de 89 años de edad con diabetes mellitus bien controlada e hipertensión arterial. Adicionalmente al síndrome típico, la paciente presentó uñas en pinza y cromoniquia amarillo-marrón. La paciente fue admitida debido a síntomas abdominales agudos asociados con diverticulitis del sigmoide y un absceso adyacente. Los estudios de imágenes revelaron cambios pulmonares y pleurales, además de un derrame pericárdico. Incidentalmente, se encontraron anomalías características de vesícula biliar en gorro frigio. Ni la enfermedad diverticular ni los trastornos de la vesícula biliar se han relacionado con el síndrome de las uñas amarillas. En el presente estudio de caso, el sincronismo entre algunas de estas condiciones podría ser casual, pero la enfermedad diverticular, colelitiasis, y hernia hiatal se asocian a esta tríada. MÉD UIS. 2015;28(3):387-91.

Palabras Clave: Divertículo del Colon. Molestias de la vesícula biliar. Hernia Hiatal. 
How to cite this article?: Santos VM, Yano VM, Alves da Cunha GLQ, Duarte ML, Soares VVP, Boggio LF. Yellow nail syndrome, Phrygian cap gallbladder and Saint's triad? Case report. MÉD UIS. 2015;28(3):387-91.

\section{INTRODUCTION}

The Yellow Nail Syndrome (YNS) is considered an uncommon condition characterized by ungual dystrophy and discoloration, associated with respiratory disturbances and lower limb edema. Worthy of note, two of these three manifestations are enough to establish the initial diagnosis. Diverse entities have been related to YNS, including malignancy, chronic renal failure, hypoalbuminemia, hypogammaglobulinemia, thyroid disorder, systemic lupus erythematosus, rheumatoid arthritis, pulmonary tuberculosis, AIDS, drug adverse effect, and familial tendency ${ }^{1-6}$. This condition is more often described in females, and may occur in all the age groups ${ }^{4,6}$. Morphological and functional disorders of lymphatic vessels have been found in many cases, but the knowledge about pathophysiological mechanisms of the syndrome remains incomplete ${ }^{1-6}$.

Pincer nails and absence of lunula have been commonly described in association with the YNS5. Phrygian cap gallbladder is considered a rare disorder more often incidentally diagnosed and although this anomaly has no pathologic significance, it may be related to cholelithiasis ${ }^{7-10}$. Colonic diverticulosis is a common disorder in elderly people and manifestations of diverticulitis more frequently occurs over the fourth decade of life, sometimes associated with cholelithiasis9.

Synchronous colon diverticulosis, cholelithiasis, and hiatal hernia make up the Saint's triad ${ }^{11-14}$, and the incidence of the association is four times greater than expected by statistical calculation ${ }^{14}$. Herniosis is a systemic disorder of connective tissue that might play a role in the Saint's triad". Casual and causal synchronism of rare or common entities may occur in daily practice, and one should consider the possibility of three or more components of the aforementioned conditions. Although with natural limitations of a single case, the main purpose of this report is to stimulate further works that might clarify possible relationship in the physiopathology of these conditions. Well understanding this issue can yield preventive and corrective measures, and better outcomes.

\section{CASe RePort}

An 89-year-old Brazilian woman, bedridden and accompanied by a caregiver for 30 years, was admitted in regular condition to the Armed Forces Hospital claiming of intense abdominal pain associated with nausea, vomiting, and soft diarrhea without blood or mucus during five days. There was also non-productive cough and fever. She denied alcohol abuse and tobacco smoking. Her medical history included type 2 diabetes mellitus, arterial hypertension, and fibrotic sequels of chronic obstructive pulmonary disease since 2011 (See Figure $1 \mathrm{~A}$ ), in addition to an ischemic stroke and cognitive deficit, which occurred two years previously. The patient complained of chronic constipation and gradually progressive changes in some nails, which raised the suspicion of onychomycosis. Nevertheless, repeated laboratory tests to discard fungal infections provided negative findings. She was in regular use of glicazide $(60 \mathrm{mg})$, metformin $(850 \mathrm{mg})$, acetylsalicylic acid $(81 \mathrm{mg})$, memantine (20 mg), losartan (100 mg), amlodipine (5 mg), calcium supplements ( 1 tablet), escitalopram (10 $\mathrm{mg})$, and betahistine dihydrochloride (16 mg).

Moreover, she was using oxygen by nasal catheter $1 \mathrm{~L} / \mathrm{min}$, with a pulse oximeter reading of $96 \%$. The physical findings included a body mass index of 27 $\mathrm{kg} / \mathrm{m}^{2}$, waist circumference of $122 \mathrm{~cm}$, temperature of $36.9^{\circ} \mathrm{C}$, blood pressure of $136 / 69 \mathrm{mmHg}$, heart rate of $90 \mathrm{bpm}$ and respiratory rate of $19 \mathrm{rpm}$. Respiratory auscultation showed bilateral rhonchi and fine bullous crackles, with absence of normal breath sounds at both bases. The deep palpation on the left lower abdominal region elicited a sharp pain, additionally to evidence a not well delimited mass. In addition, there was bilateral lower limb edema with discrete Godet signal, yellowish discoloration in fingernails and toenails and typical features of pincer, omega or trumpet nail (See Figure 2). Routine laboratory determinations are comparatively shown in Table 1. At the moment of admission, the imaging studies revealed inflammatory changes in the basal segments of the right lung field, bilateral blunting of costophrenic angles (See Figure 1B), and pericardial effusion (See Figure 1C). 
SEPTIEMTBRE-DICIEMRBRE

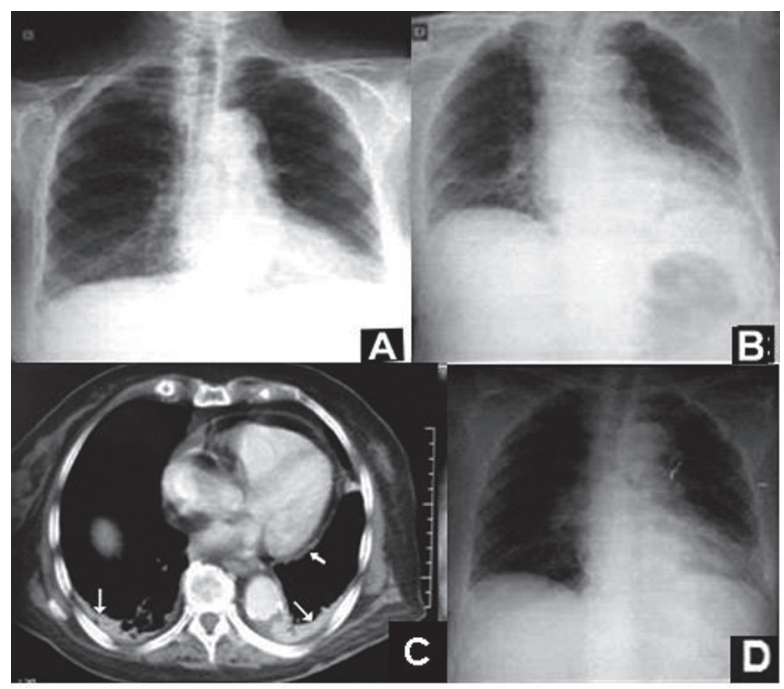

Figure 1. A. Radiography of the chest taken during an ambulatory consultation in 2011, showing features of chronic obstructive pulmonary disease and fibrotic sequels, in addition to heart enlargement and blunting of the left costophrenic angle. B. Image of the chest on the current admission, revealing changes in the basal segments of the right lung field, and bilateral blunting of costophrenic angles, mainly on the left side. C. Computed tomography images of thorax on the current admission revealing atelectasis, bilateral pleural effusion (thin arrows), and pericardial effusion (short arrow). D. Control of pulmonary and pleural changes after clinical treatment

Source: Authors.

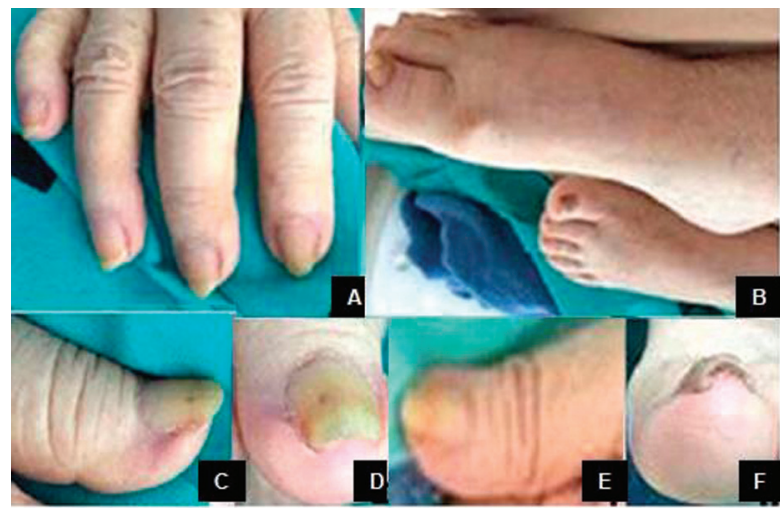

Figure 2. A-F. Yellowish discoloration in fingernails and toenails, most of them showing features of pincer nails; B. Bilateral lower limb edema; C-E. Typical pincer nails in the first toes; F. Left first toe affected by yellow-brownish chromonychia, in addition to pincer nail

Source: Authors.

Computed tomography images with contrast of the abdomen and pelvis disclosed a Phrygian cap gallbladder (See Figures $3 \mathrm{~A}$ to $3 \mathrm{D}$ ), small hiatus hernia (See Figures $3 \mathrm{E}$ and $3 \mathrm{~F}$ ), diverticulosis and sigmoid diverticulitis (See Figure $3 \mathrm{G}$ ), and an adjacent abscess measuring $8.4 \times 3.6 \times 3.0 \mathrm{~cm}$ and $47.8 \mathrm{~cm}^{3}$ (See Figure $3 \mathrm{H}$ ). The patient had a dietary and clinical management, and underwent an antimicrobial schedule with metronidazole (1500 mg/day) and
YELLOW NAIL SYחDROME, PHRYGIFก CAP GALLBLADDER AחD SAIOT'S TRIAD? CASE REPORT

ciprofloxacin (1200 mg/day) for 14 and 10 days, respectively. The total time of her hospitalization was 40 days, and with clinical and imaging improvement (See Figure 1D), she was referred to outpatient follow-up.

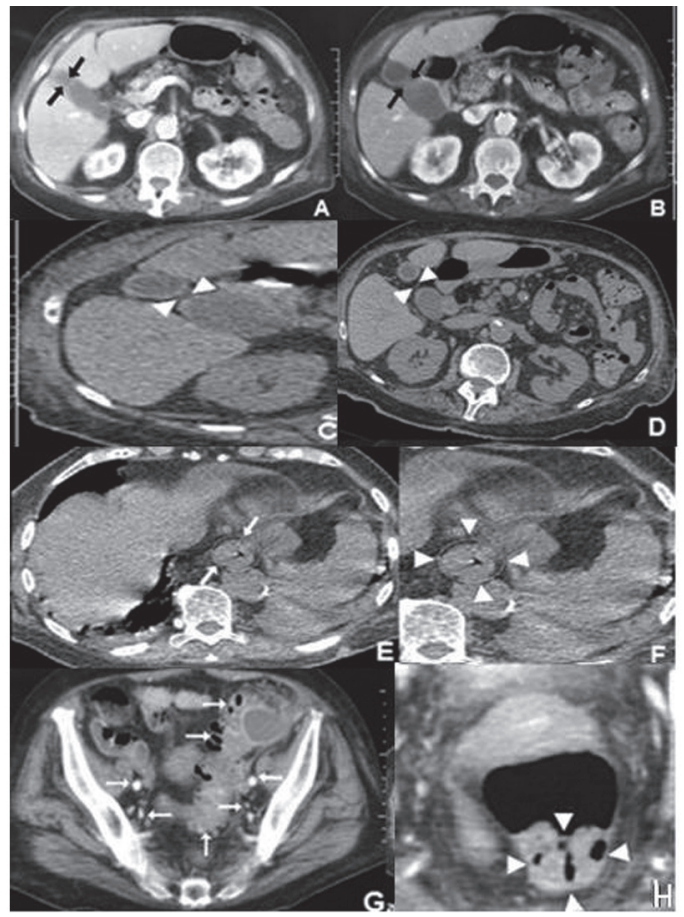

Figure 3. Computed tomography images with contrast of the abdomen and pelvis during the current admission. A-D. Classical features of the incidentally detected Phrygian cap gallbladder (arrows and arrowheads), with some images mimicking a bilobed gallbladder (arrowheads); E-F. Small hiatus hernia (encircled, arrows and arrowheads); G. Widespread colonic diverticulosis (arrows); H. Sigmoid diverticulitis evolving with adjacent conspicuous abscess (arrowheads)

Source: Authors.

\section{Discussion}

\section{YELLOW NAIL SYNDROME AND GREAT TOENAIL DYSTROPHY}

YNS is currently considered an uncommon condition, but it seems to be relatively frequent among elderly people, and possibly has evolved unsuspected or less reported. This syndrome can be idiopathic and familiar, or can develop in association with diverse benign and malignant conditions ${ }^{1-6}$. Concordant with the literature, pincer (omega or trumpet) nails were also observed in the present case, characterized by excessive transverse curvature of the nail plates ${ }^{3-5}$. This woman had hypertension, but renal failure, hypothyroidism, and cancer were ruled out. She 
presented the complete features of the YNS, and had other seemingly unrelated entities. Pulmonary and pleural changes were coexistent with pericardial effusion ${ }^{2}$, which is rare in YNS.

A very peculiar aspect was found on the right first toenail of this patient (See Figure 2F). In addition to the characteristics of the pincer nail, there was a yellowbrownish discoloration, which can be consistent with the hypothesis of concomitant acquired first toenail dystrophy ${ }^{15}$. This nail dystrophy is accompanied by growth retardation, and has been also scarcely reported'5. Kim et al. reviewed data from 21 patients with this diagnosis, $85 \%$ were woman, the mean age was 43 years old (range: 17 to 88 years old) and main co-morbidities were hypertension and diabetes ${ }^{15}$.

The pathophysiology of YNS as well as first toenail dystrophy remains elusive. Disordered lymphatic drainage has been one of the proposed etiologic mechanisms of the $\mathrm{YNS}^{1-6}$. Great toenail dystrophy can be a congenital or acquired phenomenon, more often due to trauma ${ }^{15}$, and the possibility of eventual trauma on the great toe was not ruled out in the present case study. However, this event did not explain the development of the associated yellowish chromonychia. An alternative hypothesis might be a common factor playing a role both in the YNS and the dystrophy ${ }^{15}$, specially if one takes into account the repeatedly negative results of the search for onychomycosis.

\section{SAINT'S TRIAD AND PHRYGIAN CAP GALLBLADDER}

The association of hiatus hernia or other primary hernia, cholelithiasis, and colon diverticulosis characterizes the triad that was first described in 1948. Estimated frequency of this condition is up to eight times higher than expected. A proposed causal phenomenon might be herniosis, which is a disorder of extracellular matrix affecting the colon and other organs $^{11-13}$. Chronic obstructive pulmonary disease, hypertension, diabetes, and aging are related to the triad", and they coexisted with phrygian cap gallbladder in the present case. This gallbladder anomaly results from congenital kinking between the body and the fundus or infundibulum, and can play a role in cholelithiasis'. Phrygian cap can share some features with the diverticulum, including the eventual volvulus; and a volvulus with cholelithiasis was reported by McAleese et al. as initial clue of the Saint's triad ${ }^{12}$.

Table 1. Comparative determinations from an 89 -year-old woman with yellow nail syndrome

\begin{tabular}{|c|c|c|c|c|c|c|c|}
\hline Parameters (2015) & D1 & D5 & D9 & D12 & D16 & D19 & D38 \\
\hline Red cells (4.7-6.0 x 1012/L) & 4.5 & 4.2 & 4.0 & 4.0 & 4.1 & 4.1 & 4.2 \\
\hline Hemoglobin (13.5-18 g/dL) & 13.9 & 13.9 & 12.5 & 12.2 & 12.4 & 12.4 & 13.0 \\
\hline Hematocrit (42-52\%) & 40.2 & 36.4 & 36.0 & 35.2 & 36.2 & 36.8 & 37.5 \\
\hline Leukocytes (4-11 x 109/L) & 12.6 & 11.5 & 11.8 & 10.2 & 12.0 & 10.0 & 10.2 \\
\hline Segmented/ bands (\%) & $56 / 17$ & $72 / 7$ & $75 / 6$ & $71 / 3$ & $65 / 2$ & $68 / 1$ & $61 / 7$ \\
\hline Platelets (>150 x 10\%/L) & 129 & 187 & 291 & 298 & 255 & 246 & 270 \\
\hline Glucose (70-100 mg/dL) & 238 & - & - & 128 & - & - & 100 \\
\hline Magnesium (1.6-2.5 mg/dL) & 0.5 & 1.5 & 1.5 & 1.5 & - & 1.3 & 1.9 \\
\hline Ionic calcium (1.12-1.32 mmol/L) & 1.49 & - & 1.52 & 1.30 & - & - & 1.51 \\
\hline Sodium (136-145 mmol/L) & 137 & 135 & 136 & 137 & 137 & 135 & 137 \\
\hline Potassium (3.5-5.2 mmol/L) & 2.9 & 4.0 & 4.9 & 3.3 & 3.7 & 3.9 & 4.2 \\
\hline Urea (16.6-48.5 mg/dL) & 38.9 & 17.9 & 18.4 & 7.10 & 10.0 & 10.2 & 28.8 \\
\hline Creatinine $(<1.2 \mathrm{mg} / \mathrm{dL})$ & 0.5 & 0.4 & 0.4 & 0.2 & 0.2 & 0.3 & 0.4 \\
\hline AST $(<39$ IU/L) & 16.4 & - & 11.5 & 11.3 & 8.5 & 9.7 & 8.1 \\
\hline $\operatorname{ALT}(<42$ IU/L) & 9.8 & - & - & 9.4 & 14.6 & 9.2 & 10.4 \\
\hline ALP (35-105 IU/L) & 127.5 & - & - & - & 74.7 & - & - \\
\hline Procalcitonin $(<0.5 \mathrm{ng} / \mathrm{mL})$ & 1.33 & 0.20 & - & - & - & - & - \\
\hline $\mathrm{CRP}(<0.5 \mathrm{mg} / \mathrm{dL})$ & 6.0 & - & - & 0.7 & 1.2 & - & - \\
\hline
\end{tabular}

D: Days of hospitalization (admitted on March 28). D38: day of hospital discharge. Leukocyte normal ranges (\%): segmented (45-70), bands (0-5). AST: Aspartate transaminase. ALT: Alanine transaminase. ALP: Alkaline Phosphatase. CRP: C-reactive protein. Not done: (-) Abnormal findings are shown in bold.

Source: Authors. 
The comments about Saint's triad in the present report are based on the synchronous evidence of colon diverticulosis or diverticulitis, hiatus hernia and congenital gallbladder anomaly. A possible favorable argument is about asymptomatic chronic cholecystitis developing in folded gallbladders, which might be associated with a sluggish bile flow previously described ${ }^{7-10}$.

In 2003, Terada reviewed histopathological data from 540 cholecystectomies performed in patients aged between 18 and 93 years old (mean age: 64.75 \pm 14.4 years old) and predominantly females. Benign and malignant lesions were detected, including inspissated bile and microliths (20\%), cholesterolosis and xanthogranulomatous alterations (15.8\%), and cholesterol polyps (6\%) ${ }^{16}$. Interestingly, these changes can play some role in the chronic cholecystopathy of Saint's triad, which may evolve clinically unsuspected, as well as undetected by routine imaginology studies. As a whole, the aforementioned factors seem to indicate that phrygian cap anomaly and allied changes could be included among the gallbladder disturbances associated with the Saint's triad. In spite of a broad literature search, we actually did not find sufficient data to support the eventual inclusion of acalculous disturbances of gallbladder in the setting of the Saint's triad.

\section{CONCLUSIONS}

The present case study involves conditions that have been considered uncommon or rare; however, the authors strongly believe that respective frequencies are probably underestimated. Moreover, one can not elucidate their pathophysiological mechanisms with scarce available data. Therefore, analysis of findings from the syndrome and the triad herein described might contribute to enhance the suspicion index about two conditions which that might share some causal mechanisms. Considering the theory of extracellular matrix changes, the deviation of developmental process affecting gallbladder, colon and diaphragm, could be related to manifestations of the YNS too. The authors believe that case studies may contribute to further clear eventual shared mechanisms.

\section{ACKNOWLEDGEMENTS}

The authors would like to thank Almir José Batista, the official photographer of the Armed Forces Hospital, in Brasília-DF, Brazil, for preparing the images illustrating this case study.

\section{Biblographic References}

1. Santos VM, Marques HV Jr, Lima Cdo C, Turra TZ, de Melo Jr Nogueira PR, Lima LN. Yellow nail syndrome and adnexal tumour: causal or casual association? Indian J Chest Dis Allied Sci. 2010;52(1):51-3.

2. Santos VM, Araújo MCM, Almeida ACA, Brito KRA, Fachinelli LR, Mussi P. Onicofagia, onicotilomania y síndrome de las uñas amarillas en mujer de 70 años. Prensa Med Argent. 2013;99(10):684-91.

3. Santos VM, Blanger V, Cançado ACV, Carvalho MRM, Araújo MCM, Silva RF. Idosa com síndrome das unhas amarelas e unhas em pinça. Rev Med Saude Brasília. 2014;3(2):125-30.

4. Santos VM, Ribeiro KRA, Santos AMRO, Nascimento ALO, Fachinelli LR, Cavalcanti GF. Síndrome das unhas amarelas em idosa com hipotireoidismo: relato de caso. Bras Med. 2013;50(4):342-5.

5. Santos VM, Ribeiro MG, Gondim Neto MC, Motta IM, Barros MF, Leme BAP. Elderly woman with yellow nail syndrome, rheumatoid arthritis and hypothyroidism. Rev Med Vozandes. 2014;25(1-2):43-6.

6. Santos VM, Sá DAR, Paz BCS, Vasconcelos RA, Santos SC, Santos FHB. Half-and-half nails and yellow nail syndrome in hemiplegic patient with renal failure. Bras Med. 2010;47(3):364-7.

7. de Csepel J, Carroccio A, Pomp A. Soft-tissue images. "Phrygian cap" gallbladder. J Can Chir. 2003;46(1):50-1.

8. Kannan NS, Kannan U, Babu CPG. Congenital bilobed gallbladder with Phrygian cap presenting as calculus cholecystitis. J Clin Diag Res. 2014;8(8):ND05-6.

9. Rafailidis V, Varelas S, Kotsidis N, Rafailidis D. Two congenital anomalies in one: an ectopic gallbladder with Phrygian cap deformity. Case Rep Radiol. 2014:246476.

10. Van Kamp MJS, Bouman DE, Steenvoorde P, Klaase JM. A Phrygian cap. Case Rep Gastroenterol. 2013;7(2):347-51.

11. Hauer-Jensen M, Bursac Z, Read RC. Is herniosis the single etiology of Saint's triad? Hernia. 2009;13(1):29-34.

12. McAleese P, Kolachalam R, Zoghlin G. Saint's triade presenting as volvulus of the gallbladder. J Laparoendosc Surg. 1996;6(6):421-5.

13. Read RC. The Nyhus-Wantz lectureship: etiology, herniosis, diverticulosis coli, and cancer. Hernia. 2011:15(5):481-3.

14. Scaggion G, Poletti G, Riggio S. Saint's triad. Statisticoepidemiologic research and case contribution. Minerva Med. 1987;78(15):1183-7.

15. Kim M, Kang JH, Cho BK, Song CH, Ock SM, Park HJ. Great toenail dystrophy: a single-center experience and review of the literature. Korean J Fam Med. 2015;36(2):113-20.

16. Terada T. Histopathologic features and frequency of gallbladder lesions in consecutive 540 cholecystectomies. Int J Clin Exp Pathol. 2013;6(1):91-6. 